|| ISSN(online): 2589-8698 || ISSN(print): 2589-868X ||

International Journal of Medical and Biomedical Studies Available Online at www.ijmbs.info

NLM (National Library of Medicine ID: 101738825)

Index Copernicus Value 2020: 79.44

Original Research Article

Volume 5, Issue 12; December: 2021; Page No. 35-36

\title{
A DESCRIPTIVE CROSS-SECTIONAL STUDY TO ASSESS PREVALENCE OF MAL-NUTRITION IN CHILDREN UNDER FIVE YEARS AGE IN RURAL COMMUNITY BIKANER, RAJASTHAN
}

\author{
Dr Poonam Meena ${ }^{1}$, Dr Satish Meena ${ }^{2 *}$, Dr Ashok Meena ${ }^{3}$, Dr R N Sehra ${ }^{4}$, \\ ${ }^{1}$ Medical Officer Government Hospital Dausa \\ ${ }^{2}$ FNB Fellow, Pediatric Hematology and Oncology, Apollo Hospital Chennai \\ ${ }^{3}$ Medical Officer Government Hospital Dausa \\ ${ }^{4}$ Senior professor, Department of Paeditrics, S M S Medical College Jaipur
}

Article Info: Received 10 October 2021; Accepted 21 November 2021

DOI: https://doi.org/10.32553/ijmbs.v5i12.2332

Corresponding author: Dr Satish Meena

Conflict of interest: No conflict of interest.

\section{Abstract}

Background: Malnutrition among children below five years continues to be one of India major human development challenges. In spite of tremendous economic progress made in the last two to three decades.

Methods: The study was cross-sectional hospital based study. Under five year children with sample size of 500 was taken for study.

Results: All three parameters of malnutrition i.e. wasting, underweight and stunting were more common in males than females. It was found that there was very significant and highly significant difference with regard to underweight and stunting respectively between male and female children but no significant gender difference was found for wasting

Conclusions: Majority of under five children were malnourished and malnutrition common in males than females.

Keywords: Malnutrition, Wasting, Stunting, Underweight, Children

\section{Introduction}

Malnutrition is defined as a pathological state resulting from absolute or relative deficiency or excess of one or more of the nutrients that are considered essential for normal life. ${ }^{1}$

Malnutrition among children below five years continues to be one of India major human development challenges. In spite of tremendous economic progress made in the last two to three decades. Malnutrition among children in rural India still claims many lives. However, mounting cases of malnutrition has caught the public eye and so healthcare providers as well as the government are taking the necessary steps to improve the current status of nutrition for children in India.

According to UNICEF to Pneumonia (30\%) and Diarrhoea $(27 \%)$ are directly related to over $50 \%$ childhood deaths. $35 \%$ of all deaths was caused because child was undernourished. $^{2}$ There is high under five morbidity and mortality in India. ${ }^{3}$ Protein energy malnutrition is major contributory factor in majority of these childhood morbidities and mortalities. At present $65 \%$ under five children are underweight which includes $47 \%$ moderate and $18 \%$ severe case of malnutrition (UNICEF 2006 state of words children). ${ }^{4}$

\section{Methods}

The study was cross-sectional hospital based study. Anthropometric measurements were carried outfollowing standard methods. The data included weight, recumbent length (for children less than 24 months of age) and height (for children more than 24 months of age). Weight was measured to the nearest $0.1 \mathrm{~kg}$ and salter weighing machine was used for weight measurement. Height was measured against a non- stretchable tape fixed toa vertical wall with the participant standing on level of surface and it was measured to the nearest $0.5 \mathrm{~cm}$. Recumbent length was measured by using an infant measuring board. Socioeconomic status was determined by using modified Prasad scale. $^{5}$

Standard statistical method was used in the analysis of the data with use of MS Excel and EPi-info software

3.4.3. $\mathrm{P}$ value was used to examine the relation between variable. Data of the nutritional survey were analysed using WHO Anthro for personal computer, version 3.1.2010. ${ }^{6}$

WHO classification was used for the assessment of malnutrition. Based on age, body weight and height, a number of indices such as height-for-age, weight-for-age and weight-for-height have been suggested. ${ }^{7}$ The children 
are classified using three categories: underweight (low weight for age), stunting (low height for age) or wasting (low weight for height). Low anthropometric values are those more than 2 SD away from the CDC 2000 (centres for disease control and prevention) standards. ${ }^{7-9}$

Results

Table 1: Occurrence of malnutrition in children by gender.

\begin{tabular}{|l|l|l|l|}
\hline Age in year & $\begin{array}{l}\text { Malnourishment } \\
\text { present }\end{array}$ & $\begin{array}{l}\text { Malnourishment } \\
\text { absent }\end{array}$ & total \\
\hline Male & 112 & 135 & 247 \\
\hline female & 89 & 164 & 253 \\
\hline total & 201 & 299 & 500 \\
\hline $\mathrm{X}^{2}$ & 5.12 & & \\
\hline $\mathrm{df}$ & 1 & & \\
\hline P value & $<0.05$ & & \\
\hline
\end{tabular}

All three parameters of malnutrition i.e. wasting, underweight and stunting were more common in males than females. It was found that there was very significant and highly significant difference with regard to underweight and stunting respectively between male and female children but no significant gender difference was found for wasting.

\section{Discussion}

Protein calories malnutrition is a widespread nutritional disease in developing countries. ${ }^{10}$ As well as mentioned by Gupta et al. ${ }^{11}$ Under five year children are notoriously fraught with the risk of malnutrition and the prevalence of malnutrition varies between $50-80 \%$. Majority of the children in our study were suffering from protein energy malnutrition. A larger proportion of males were suffering malnutrition as compared to females. The same result were found in the study of Zottarelli LK, Mittal et al, and Sengupta et al. ${ }^{12-14}$

It was found in study that malnourishment in the form of underweight was most common in the study sample followed by stunting and wasting. similar proportion of wasted children was reported in NFHS-3 (national as well as of Rajasthan) whereas according to NFHS-3, proportion of underweightand stunted children differed nationally as state-wise ( $43 \%, 48 \%$ in India respectively; $40 \%, 44 \%$ in Rajasthan respectively).

\section{Conclusion}

Majority of under five children were malnourished and malnutrition common in males than females.

\section{References}

1. Park JE, Park K. Park textbook of preventive of social medicine $19^{\text {th }}$ Edition. Jabalpur Banarsidas Bhanol, 2007.

2. Undernutritions impact on child death by illness (internet) UNICEF. Cited 2013 July 13. Available from: http://www.unicef.org/nutrition/2.2/4.html.
3. Park JE, Park K. Park textbook of preventive of social medicine $18^{\text {th }}$ Edition. Jabalpur Banarsidas Bhanol, 2005.

4. Progress for children. A report card nutrition UNICEF: Times of India, 2006.

5. Kumar P. Social classification needs constant upgrading. Ind. J. Comm. Med. 1993;18(2):60-1.

6. Software for assessing growth and development of the WHO 2010. Available from htpp://www. Who.int/childgrowth/software/en.

7. Waterlow IC, Buzina R, Keller W. Presentation and use of height and weight data comparing thenutritional status of groups of children under age 10 years. Bull World Health organ. 1977;55(4):489-98.

8. Kuczmaksi RJ, Ogden CL, Guo SS. CDC Growth Charts for the United States: methods and development. Vital Health Stat. 2002;11(246):1-190.

9. WHO Expert Committee on physical status: the use and interpretation of anthropometry, report of a WHO exp committee, Geneva. Available from http://whqlibdoc.who.int/trs/WHO_TRS_854.

10. Chakraborty S, Gupta SB, Chaturvedi $\overline{S K}$. A study of protein energy malnutrition in children in rural area. Indian journal of Community Medicine. 2006:31(4):291-2.

11. Gupta VM, Shukla KK. Epidemiological correlates of protein energy malnutrition in preschool children. Ind J Prev Soc Med. 1992;23:26-32.

12. Zottarelli LK, Sunil TS. Influence of prenatal and socioeconomic factors on stunting in children under

13. 5 years in Egypt. East Meditter Health J. 2007;13(6):1330-42.

14. Mittal A, Singh J. Effect of maternal factors on nutrition status of 1-5 years children in urban slum population. Indian J community Med Oct. 2007;32(4):264-7.

15. Sengupta P, Philip N. Epidemiological correlates of undernutrition in under 5 year children an slum of Ludhiana. Health and population: perspective and issues. 2010;33(1):1-9 